\title{
Morphometric Analysis of Cervical Spinal Cord and Spinal Canal with Magnetic Resonance Imaging in Turkish Adults
}

\section{Türk Yetişkinlerde Manyetik Rezonans Görüntüleme ile Servikal Spinal Kord ve Spinal Kanalın Morfometrik Analizi}

\author{
Nurullah Dag', @Nesrin Erdoğan Kaydu', @Muhammed Samed Cansız², $\odot$ Mehmet Öztürk² \\ 'Malatya Training and Research Hospital, Department of Radiology, Malatya, Turkey \\ ${ }^{2}$ Selçuk University Faculty of Medicine, Department of Radiology, Konya, Turkey
}

\begin{abstract}
Aim: We aimed to evaluate the normal values of cervical spinal canal diameter and spinal cord diameter-area by magnetic resonance imaging (MRI) in adult Turkish population, in this study. It was investigated whether the values changed according to age, gender and spinal cord levels.
\end{abstract}

Material and Method: We retrospectively examined cervical MRI of 300 adult patients (150 female / 150 male). The patients were divided into 3 groups (18-39, 40-59 and over 60 years old) according to their age. Spinal canal and spinal cord diameter were measured in the sagittal plane and the spinal cord area in the axial plane from the $\mathrm{C} 3$ and $\mathrm{C} 6$ levels.

Results: Gender affects the normal values of the cervical spinal canal and spinal cord diameter. Both spinal cord and spinal canal measurements were found to be higher in men than in women. Spinal cord diameter and area were found to be lower at the C6 level than at the $\mathrm{C} 3$ level, regardless of gender. Both spinal canal diameter and spinal cord area decreased from cranial to caudal (C3-C6). Significant differences were detected in our data in the evaluation of age-related groups, and age was found to be effective in determining the normal parameter.

Conclusion: In conclusion, cervical spinal canal and spinal cord measurements in healthy individuals vary depending on age, gender and cord level.

Keywords: Magnetic resonance imaging, cervical spine, spinal cord, spinal canal, morphometry
Öz

Giriş: Yetişkin Türk popülasyonunda servikal spinal kanal çapı ve spinal kord çap-alanı normal değerlerinin manyetik rezonans görüntüleme (MRG) ile değerlendirilmesi amaçlandı. Değerlerin yaşa, cinsiyete ve spinal kord düzeylerine göre değişip değişmediği araştırıldı.

Gereç ve Yöntem: 300 erişkin hastanın (150 kadın / 150 erkek) servikal MRG'sini geriye dönük olarak inceledik. Hastalar yaşlarına göre 3 gruba (18-39, 40-59 ve 60 yaş üstü) ayrıldı. Spinal kanal ve spinal kord çapı sagital planda, spinal kord alanı aksiyal planda, C3 ve C6 seviyelerinden ölçüldü.

Bulgular: Cinsiyet, servikal spinal kanal ve spinal kord çapı normal değerlerini etkiler. Erkeklerde hem spinal kanal hem de spinal kord ölçümleri kadınlara göre daha yüksek bulundu. Spinal kord çapı ve alanı, cinsiyete bakılmaksızın C6 düzeyinde C3 düzeyindekinden daha düşük bulundu. Hem spinal kanal çapı hem de omurilik alanı kranialden kaudale azaldı (C3-C6). Yaşa bağlı grupların değerlendirilmesinde verilerimizde önemli farklılıklar tespit edilmiş ve yaşın normal parametrenin belirlenmesinde etkili olduğu görülmüştür.

Sonuç: Sonuç olarak, sağlıklı bireylerde servikal spinal kanal ve spinal kord ölçümleri yaş, cinsiyet ve kord düzeyine göre değişmektedir.

Anahtar Kelimeler: Manyetik rezonans görüntüleme, servikal vertebra, spinal kord, spinal kanal, morfometri

Corresponding (illetişim): Nurullah Dag, Malatya Training and Research Hospital, Department of Radiology, Turgut Özal Bulvarı No:4 44090 Yeşilyurt, Malatya, Turkey

E-mail (E-posta): drndag@icloud.com

Received (Geliș Tarihi): 25.08.2021Ａccepted (Kabul Tarihi): 12.09 .2021 


\section{INTRODUCTION}

It is important to know the normal parameters of the cervical spinal cord and spinal canal in the evaluation of degenerative, traumatic and inflammatory conditions. ${ }^{[1]}$ Age, gender, body mass index and spinal cord level are the parameters that should be taken into account in spinal cord and spinal canal measurements. ${ }^{[2]}$ Normal cervical spinal cord and spinal canal measurements determined using the these parameters are required for the detection and differential diagnosis of possible pathologies.

There are many studies about evaluating canal diameter, canal-corpus ratio, and interpeduncular distance measurements via conventional radiographs and computed tomography. ${ }^{[3-8]}$ However, these imaging techniques are insufficient for soft tissue evaluation. Today, magnetic resonance imaging ( $\mathrm{MRI}$ ) is the most effective and widely used in the evaluation of the cervical spinal canal. With MRI, both soft tissue and bone structures are evaluated, spinal canal and spinal cord dimensions are measured accurately. [9] There are relatively few studies in the literature evaluating cervical spinal canal and cord diameters with MRI. In this study, it was aimed to evaluate the normal values of cervical spinal canal diameter and spinal cord diameter-area by MRI in an adult Turkish population.

\section{MATERIAL AND METHOD}

A local ethics committee approved this single-center retrospective study (2021/98). Patients over the age of 18 who underwent cervical MRI (indication: neck-shoulder pain, disc herniation, etc.) in our center between June 2016 and December 2020 were randomly selected and included in the study. The patients were divided into 3 groups according to their age (18-39, 40-59 and over 60 years old). A total of 300 patients were selected, with 50 male and 50 female patients in all age groups. Exclusion criteria; spinal stenosis (spinal canal diameter $<10 \mathrm{~mm}$ ), compressive myelopathy (change in spinal cord signal and diameter), spinal cord tumor, spinal cord ischemia, spinal cord injury, history of head and neck surgery, trauma and pregnancy.

All examinations were performed with a 1.5 Tesla MR system (Sonata; Siemens Medical Solutions, Erlangen, Germany). Imaging was obtained with patients in a neutral supine position. T2-weighted sagittal turbo spin echo sequence (time-to-echo 108 ms; time-to-repetition 3000 ms; slice thickness:3.4 mm; field of view 568x640) and T2-weighted axial (time-to-echo 105 ms; time-to-repetition 4280 ms; slice thickness:3.0 mm; field of view 608x608) images were used for measurements. Anterior-posterior (AP) spinal canal and spinal cord diameter were measured at the mid-vertebral level C3 and C6 in the sagittal plane (Figure 1). Spinal cord area was measured at the disc levels in the axial plane using a manual measurement (Figure 2). All measurements were made by the same radiologist.

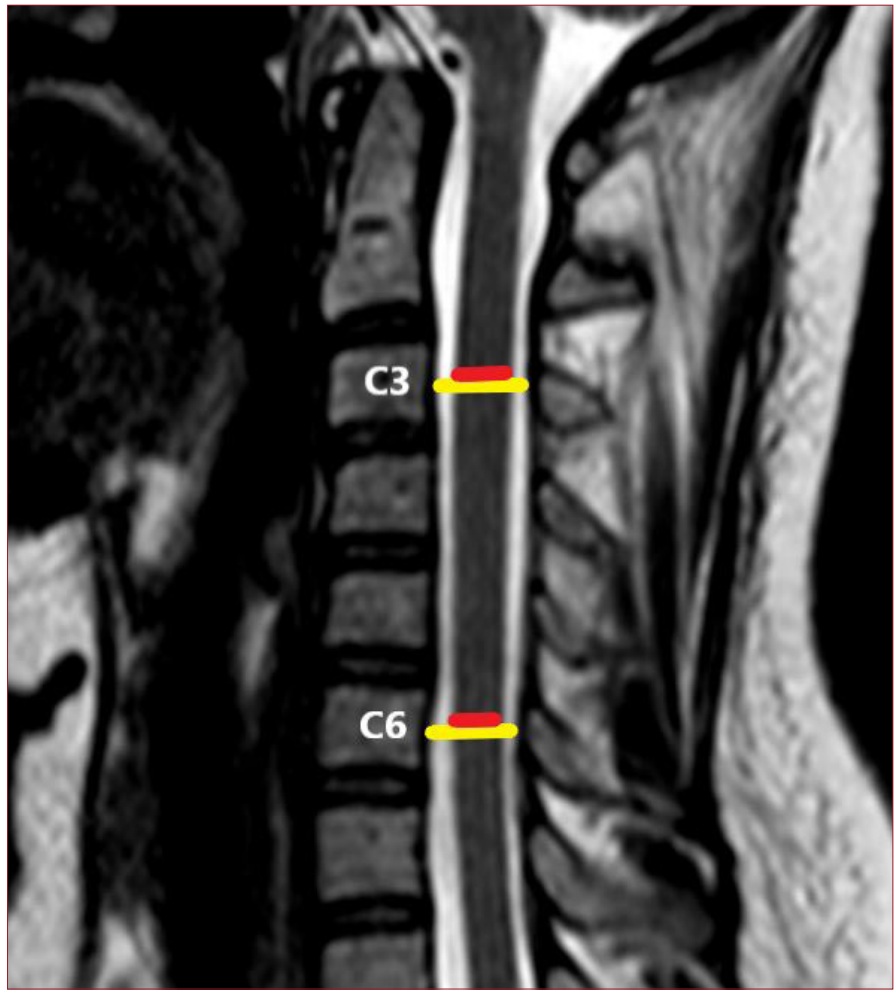

Figure 1. Antherio-posterior (AP) spinal canal (red line) and spinal cord (yellow line) diameter at the mid-vertebral level $\mathrm{C} 3$ and $\mathrm{C} 6$ in the sagittal plane.

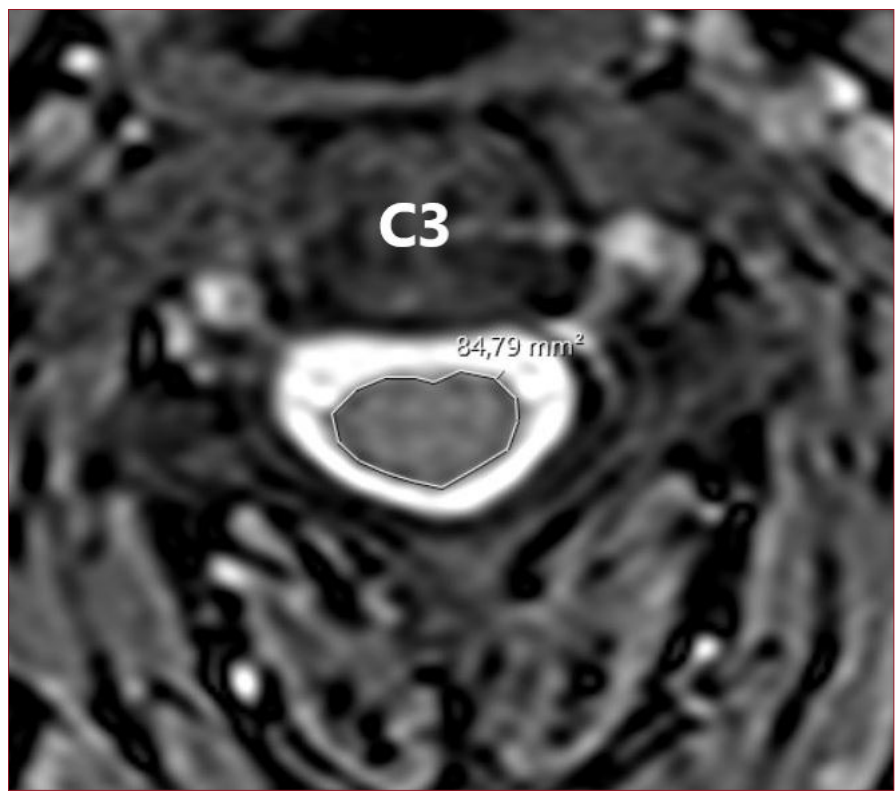

Figure 2. Spinal cord area at the $\mathrm{C} 3$ level in the axial plane.

\section{Statistical Analysis}

All statistical analysis was performed by using SPSS 23.0 (IBM, Armonk, NY, USA), and p values less than 0.05 was considered statistically significant. Average values of AP spinal canal and cord diameter in sagittal plane and cord area in axial plane were calculated at C3 and C6 levels. The measured values for each level were calculated separately according to age groups and gender. Student's t-test was 
used to compare two independent groups, and the Anova test was used to compare three or more groups while comparing them according to gender and age groups. It was observed that age groups were distributed homogeneously and Bonferroni test was used for Post Hoc evaluation. While evaluating among age groups, $p$ value was accepted as 0.017 , since there are 3 independent variables.

\section{RESULTS}

A total of 300 patients, 150 men and 150 women, participated in the study. The mean age of the patient group over the age of 60 was $68.7 \pm 5.7$ years, the mean age of the $40-59$ age group was $46.18 \pm 5.1$ years, and the mean age of the 18-39 age group was $28.19 \pm 6.3$ years. The mean age of the female population was $48.26 \pm 17.5$ years (range, 18.7-85.6 years), the mean age of the male population was $46.99 \pm 17.5$ years (range, 18.2-83.4 years).

The spinal canal diameter was calculated as $12.04 \pm 1.16 \mathrm{~mm}$ at the C3 level and $12.21 \pm 1.33 \mathrm{~mm}$ at the C 6 level. It was observed that there was no significant difference in cord diameter between these levels ( $p>0.05$ ). Cord diameter mean values at the $C 3$ level are $6.78 \pm 0.65 \mathrm{~mm}$, at C6 level $6.20 \pm 0.60 \mathrm{~mm}$; cord area mean values $69.87 \pm 8.77 \mathrm{~mm}^{2}$ at C3 level, $63.73 \pm 8.15 \mathrm{~mm}^{2}$ at C6 level. It was observed that the difference between cord diameter and area at $\mathrm{C} 3$ and $\mathrm{C} 6$ levels was significant $(p<0.05)$. As a result, it was found that the cord diameter and area were lower at the $\mathrm{C} 6$ level than at the C3 level (Table 1).

In Table 2, mean values for each level by gender are given and the difference between them is evaluated. In all three parameters, the difference between the male and female groups was found to be significant; the canal, cord diameter and cord area were found to be larger in the male population $(p<0.05)$. Table 3 shows the mean values and Anova analysis results by age groups. A significant difference was found between the parameters except the C 6 cord area by age groups $(p<0.05)$.

Analysis of the difference between age groups was done with the Bonferroni test (Table 4). The results between the ages of $18-40$ and over 60 were found to be significant. It was observed that the spinal canal diameter and cord diameter decreased over the age of 60 compared to other age groups $(p<0.017)$.

\section{DISCUSSION}

The studies on spinal canal and cord measurements in the cervical region date back to the early 1900s. In the early periods, studies were conducted with a limited number of samples using cadavers. With the development of imaging techniques, studies that can reach large populations and use different variables can be performed. Vertebral and spinal canal measurements are more prominent in studies performed with conventional radiographs and computed tomography. ${ }^{[3,7,10,11]}$
Table 1. The mean values according to $\mathrm{C} 3$ and $\mathrm{C} 6$ levels.

\begin{tabular}{lccccc} 
Variables & Level & $\mathbf{N}$ & Mean & SD & p \\
\hline $\begin{array}{l}\text { Spinal canal } \\
\text { diameter }\end{array}$ & C3 & 300 & 12.29 & 1.21 & \\
\hline Spinal cord & C6 & 300 & 12.21 & 1.33 & 0.4 \\
diameter & C6 & 300 & 6.78 & 0.65 & \\
\hline \multirow{2}{*}{ Spinal cord area } & C3 & 300 & 6.20 & 0.60 & $<0.05$ \\
& C6 & 300 & 63.73 & 8.15 & $<0.05$ \\
\hline
\end{tabular}

Table 2. Differences according to gender

\begin{tabular}{llcccc} 
Variables & Gender & N & Mean & SD & p \\
\hline Spinal canal & Female & 150 & 12.04 & 1.16 & \\
diameter at C3 & Male & 150 & 12.54 & 1.22 & $<0.001$ \\
& Female & 150 & 6.67 & 0.66 & \\
Spinal cord & Male & 150 & 6.87 & 0.62 & $<0.05$ \\
diameter at C3 & Female & 150 & 66.96 & 8.33 & \\
Spinal cord & Male & 150 & 72.94 & 8.34 & $<0.001$ \\
area at C3 & Female & 150 & 11.97 & 1.35 & \\
Spinal canal & Male & 150 & 12.49 & 1.28 & $<0.05$ \\
diameter at C6 & Female & 150 & 6.06 & 0.58 & \\
Spinal cord & Male & 150 & 6.34 & 0.58 & $<0.001$ \\
diameter at C6 & Female & 150 & 60.69 & 7.73 & \\
Spinal cord area & Male & 150 & 66.97 & 7.51 & $<0.001$ \\
at C6 & Male & & & & \\
\hline
\end{tabular}

Table 3. Analysis of the difference by age groups

\begin{tabular}{|c|c|c|c|c|c|c|c|}
\hline \multirow{2}{*}{ Variables } & \multirow{2}{*}{ Age } & \multirow{2}{*}{$\mathbf{N}$} & \multirow{2}{*}{ Mean } & \multirow{2}{*}{ SD } & \multicolumn{2}{|c|}{$\begin{array}{l}95 \% \text { Confidence } \\
\text { Interval for Mean }\end{array}$} & \multirow{2}{*}{$\mathbf{p}$} \\
\hline & & & & & $\begin{array}{l}\text { Lower } \\
\text { Bound }\end{array}$ & $\begin{array}{l}\text { Upper } \\
\text { Bound }\end{array}$ & \\
\hline \multirow{4}{*}{$\begin{array}{l}\text { Spinal canal } \\
\text { diameter } \\
\text { at } \mathrm{C} 3\end{array}$} & $18-40$ & 100 & 12.63 & 1.13 & 12.40 & 12.85 & \multirow{4}{*}{$<0.05$} \\
\hline & $40-60$ & 100 & 13.33 & 1.17 & 12.10 & 12.56 & \\
\hline & $>60$ & 100 & 11.91 & 1.22 & 11.67 & 12.16 & \\
\hline & Total & 300 & 12.29 & 1.21 & 12.15 & 12.43 & \\
\hline \multirow{4}{*}{$\begin{array}{l}\text { Spinal cord } \\
\text { diameter } \\
\text { at } C 3\end{array}$} & $18-40$ & 100 & 6.84 & 0.67 & 6.71 & 6.98 & \multirow{4}{*}{$<0.05$} \\
\hline & $40-60$ & 100 & 6.97 & 0.57 & 6.86 & 7.09 & \\
\hline & $>60$ & 100 & 6.20 & 0.62 & 6.38 & 6.63 & \\
\hline & Total & 300 & 6.78 & 0.65 & 6.70 & 6.85 & \\
\hline \multirow{4}{*}{$\begin{array}{l}\text { Spinal cord } \\
\text { area at C3 }\end{array}$} & $18-40$ & 100 & 70.95 & 9.45 & 69.08 & 72.83 & \multirow{4}{*}{$<0.05$} \\
\hline & $40-60$ & 100 & 71.44 & 8.18 & 69.82 & 73.06 & \\
\hline & $>60$ & 100 & 67.21 & 8.08 & 65.61 & 68.82 & \\
\hline & Total & 300 & 69.87 & 8.77 & 68.87 & 70.87 & \\
\hline \multirow{4}{*}{$\begin{array}{l}\text { Spinal canal } \\
\text { diameter } \\
\text { at C6 }\end{array}$} & $18-40$ & 100 & 12.57 & 1.17 & 12.34 & 12.80 & \multirow{4}{*}{$<0.05$} \\
\hline & $40-60$ & 100 & 12.37 & 1.39 & 12.09 & 12.64 & \\
\hline & $>60$ & 100 & 11.70 & 1.28 & 11.45 & 11.96 & \\
\hline & Total & 300 & 12.21 & 1.33 & 12.06 & 12.36 & \\
\hline \multirow{4}{*}{$\begin{array}{l}\text { Spinal cord } \\
\text { diameter } \\
\text { at } \mathrm{C} 6\end{array}$} & $18-40$ & 100 & 6.18 & 0.62 & 6.05 & 6.30 & \multirow{4}{*}{$<0.05$} \\
\hline & $40-60$ & 100 & 6.43 & 0.48 & 6.34 & 6.53 & \\
\hline & $>60$ & 100 & 5.99 & 0.61 & 5.87 & 6.11 & \\
\hline & Total & 300 & 6.20 & 0.60 & 6.13 & 6.27 & \\
\hline \multirow{4}{*}{$\begin{array}{l}\text { Spinal cord } \\
\text { area at C6 }\end{array}$} & $18-40$ & 100 & 64.03 & 8.91 & 62.26 & 65.80 & \multirow{4}{*}{0.77} \\
\hline & $40-60$ & 100 & 64.86 & 7.31 & 63.41 & 66.31 & \\
\hline & $>60$ & 100 & 62.30 & 8.02 & 60.71 & 63.89 & \\
\hline & Total & 300 & 63.73 & 8.15 & 62.80 & 64.66 & \\
\hline
\end{tabular}




\begin{tabular}{|c|c|c|c|c|c|}
\hline \multirow{2}{*}{ Variables } & & & \multirow[b]{2}{*}{$\mathbf{p}$} & \multicolumn{2}{|c|}{$98.3 \% \mathrm{Cl}$} \\
\hline & & & & $\begin{array}{l}\text { Lower } \\
\text { Bound }\end{array}$ & $\begin{array}{l}\text { Upper } \\
\text { Bound }\end{array}$ \\
\hline \multirow{6}{*}{$\begin{array}{l}\text { Spinal canal } \\
\text { diameter at C3 }\end{array}$} & \multirow{2}{*}{$\begin{array}{l}18-40 \\
\text { years }\end{array}$} & $40-60$ years & 0.229 & -0.1686 & 0.7634 \\
\hline & & $>60$ years & 0.000 & 0.2490 & 1.1810 \\
\hline & \multirow{2}{*}{$\begin{array}{l}40-60 \\
\text { years }\end{array}$} & $18-40$ years & 0.229 & -0.7634 & 0.1686 \\
\hline & & $>60$ years & 0.039 & -0.0484 & 0.8836 \\
\hline & \multirow{2}{*}{$\begin{array}{l}>60 \\
\text { years }\end{array}$} & $18-40$ years & 0.000 & -1.1810 & -0.2490 \\
\hline & & $40-60$ years & 0.039 & -0.8836 & 0.0484 \\
\hline \multirow{6}{*}{$\begin{array}{l}\text { Spinal cord } \\
\text { diameter at C3 }\end{array}$} & \multirow{2}{*}{$\begin{array}{l}18-40 \\
\text { years }\end{array}$} & $40-60$ years & 0.431 & -0.3770 & 0.1170 \\
\hline & & $>60$ years & 0.001 & 0.0900 & 0.5840 \\
\hline & \multirow{2}{*}{$\begin{array}{l}40-60 \\
\text { years }\end{array}$} & $18-40$ years & 0.431 & -0.1170 & 0.3770 \\
\hline & & $>60$ years & 0.000 & 0.2200 & 0.7140 \\
\hline & \multirow{2}{*}{$\begin{array}{l}>60 \\
\text { years }\end{array}$} & $18-40$ years & 0.001 & -0.5840 & -0.0900 \\
\hline & & $40-60$ years & 0.000 & -0.7140 & -0.2200 \\
\hline \multirow{6}{*}{$\begin{array}{l}\text { Spinal cord } \\
\text { area at C3 }\end{array}$} & \multirow{2}{*}{$\begin{array}{l}18-40 \\
\text { years }\end{array}$} & $40-60$ years & 1.000 & -3.8757 & 2.9029 \\
\hline & & $>60$ years & 0.007 & 0.3509 & 7.1295 \\
\hline & \multirow{2}{*}{$\begin{array}{l}40-60 \\
\text { years }\end{array}$} & $18-40$ years & 1.000 & -2.9029 & 3.8757 \\
\hline & & $>60$ years & 0.002 & 0.8373 & 7.6159 \\
\hline & \multirow{2}{*}{$\begin{array}{l}>60 \\
\text { years }\end{array}$} & $18-40$ years & 0.007 & -7.1295 & -0.3509 \\
\hline & & $40-60$ years & 0.002 & -7.6159 & -0.8373 \\
\hline \multirow{6}{*}{$\begin{array}{l}\text { Spinal canal } \\
\text { diameter at C6 }\end{array}$} & \multirow{2}{*}{$\begin{array}{l}18-40 \\
\text { years }\end{array}$} & $40-60$ years & 0.785 & -0.3029 & 0.7129 \\
\hline & & $>60$ years & 0.000 & 0.3591 & 1.3749 \\
\hline & \multirow{2}{*}{$\begin{array}{l}40-60 \\
\text { years }\end{array}$} & $18-40$ years & 0.785 & -0.7129 & 0.3029 \\
\hline & & $>60$ years & 0.001 & 0.1541 & 1.1699 \\
\hline & \multirow{2}{*}{$\begin{array}{l}>60 \\
\text { years }\end{array}$} & $18-40$ years & 0.000 & -1.3749 & -0.3591 \\
\hline & & $40-60$ years & 0.001 & -1.1699 & -0.1541 \\
\hline \multirow{6}{*}{$\begin{array}{l}\text { Spinal cord } \\
\text { diameter at C6 }\end{array}$} & \multirow{2}{*}{$\begin{array}{l}18-40 \\
\text { years }\end{array}$} & $40-60$ years & 0.006 & -0.4848 & -0.0272 \\
\hline & & $>60$ years & 0.066 & -0.0398 & 0.4178 \\
\hline & \multirow{2}{*}{$\begin{array}{l}40-60 \\
\text { years }\end{array}$} & $18-40$ years & 0.006 & 0.0272 & 0.4848 \\
\hline & & $>60$ years & 0.000 & 0.2162 & 0.6738 \\
\hline & \multirow{2}{*}{$\begin{array}{l}>60 \\
\text { years }\end{array}$} & $18-40$ years & 0.066 & -0.4178 & 0.0398 \\
\hline & & $40-60$ years & 0.000 & -0.6738 & -0.2162 \\
\hline
\end{tabular}

In our study, spinal cord and spinal canal measurements at C3 and $\mathrm{C} 6$ levels in the adult Turkish population were compared according to age and gender by using MRI. Studies show that gender affects the normal values of the cervical spinal canal and cord diameter. In our study, these values were found to be higher at men than women. Spinal cord measurements were found to be lower at C6 level than at C3 level, regardless of gender. There is a statistically insignificant reduction at C6 level in the diameter of the spinal canal. Significant differences were detected in the evaluation of age-related groups, and age was found to be effective in determining the normal parameter. There is a statistically significant decrease in all variables, especially in the population above 60 years old. Our results showed age and gender-related differences should be taken into account when evaluating the cervical spinal canal and spinal cord with MRI. In our study, contrary to similar studies in the literature, the spinal canal diameter decreased at the $\mathrm{C} 6$ level, while the cord area also decreased..$^{[9,11,12]}$ This situation creates a different perspective in the relative risk assessment for compressive myelopathy at the lower cervical levels.
The studies have shown that the diameter of the spinal canal decreases from the cranial to the caudal in the cervical region, and the spinal cord area increases..$^{[9,12-13]}$ This condition has been evaluated as an increasing risk factor in terms of compressive myelopathy and posttraumatic injury at the lower cervical levels. In our study, there was a non-significant decrease in the spinal canal diameter at the C6 level compared to C3. However, cervical spinal cord area and cord diameter also showed a significant decrease. Okada et al. ${ }^{[14]}$ and Sherman et al. ${ }^{[15]}$ found that the area and diameter of the cervical spinal canal decreased in C6 compared to C3, similar to our results. Considering the spinal canal diameter alone, the risk of compressive myelopathy can be mentioned. Since the space around the spinal cord decreases relatively at the lower cervical levels, the risk is dominant at these levels. ${ }^{[16,17]}$ However, different results in spinal cord area and diameter measurements raise questions about this issue. Another point that should not be forgotten is that morphometric studies may differ according to age, gender, height, weight and ethnic origin. ${ }^{[9]}$ Our study was done only at two levels. In order to make a general inference, new studies are needed in which all levels are evaluated and variables that may cause morphometric differences are taken into account.

In studies in which gender and age-related cervical spinal canal and cord were evaluated; In general, it has been found that canal and cord measurements are higher in men than women, and the measurements progressively decrease in older ages. ${ }^{[9,12,13]}$ Our results are similar to these studies. Both spinal canal and spinal cord measurements were higher in men in all age groups. There was a significant decrease in the measurements, especially over the age of 60 .

There were some limitations in our study. First of all, anthropometric measurements could not be used as variables due to the retrospective character of the study. For example, studies have reported that height may affect spinal morphometric measurements. ${ }^{[9,18]}$ Future studies using anthropometric measurement information can provide useful information on this subject. Second, intra- and inter-observer variability could not be evaluated. Third, our sample size is relatively small for morphometric study.

\section{CONCLUSION}

In conclusion, cervical spinal canal and spinal cord dimensions in healthy individuals vary according to age, gender and cord level. These results can be used as reference values in future studies on pathologies affecting cervical spinal cord dimensions.

\section{ETHICAL DECLARATIONS}

Ethics Committee Approval: The study was approved by the Selcuk University Medical Faculty Ethical Committee. (2021/98).

Informed Consent: All patients signed the free and informed consent form. 
Referee Evaluation Process: Externally peer-reviewed.

Conflict of Interest Statement: The authors have no conflicts of interest to declare.

Financial Disclosure: The authors declared that this study has received no financial support.

Author Contributions: All of the authors declare that they have all participated in the design, execution, and analysis of the paper, and that they have approved the final version.

\section{REFERENCES}

1. Morishita Y, Naito M, Hymanson H, Miyazaki M, Wu G, Wang JC. The relationship between the cervical spinal canal diameter and the pathological changes in the cervical spine. Eur Spine J 2009;18(6):877-83.

2. Kim KH, Park JY, Kuh SU, Chin DK, Kim KS, Cho YE. Changes in spinal canal diameter and vertebral body height with age. Yonsei Med J 2013;54(6):1498-504.

3. Pavlov H, Torg JS, Robie B, Jahre C. Cervical spinal stenosis: determination with vertebral body ratio method. Radiology 1987;164(3):771-5.

4. Gore Dr, Sepic Sb, Gardner Gm. Roentgenographic findings of the cervical spine in asymptomatic people. Spine 1986;11(6):521-4.

5. Sasaki T, Kadoya S, lizuka H. Roentgenological study of the sagittal diameter of the cervical spinal canal in normal adult Japanese. Neurol Med Chir 1998;38(2):83-9.

6. Matsuura P, Waters R, Adkins R, Rothman S, Gurbani N, Sie I. Comparison of computerized tomography parameters of the cervical spine in normal control subjects and spinal cord-injured patients. JBJS 1989;71(2):183-8.

7. Şenol U, Çubuk M, Sindel M, Yildirim F, Yilmaz S, Özkaynak C. Anteroposterior diameter of the vertebral canal in cervical region: comparison of anatomical, computed tomographic, and plain film measurements. Clin Anat 2001;14(1):15-8.

8. Pawar KA, Mishra AS, Bandagi G, Srivastava SK. Roentgenographic and computerized tomography based morphometric analysis of cervical spinal canal diameters to establish normative measurements in an Indian population. J Clin Orthop Trauma 2017;8(2):185-90.

9. Ulbrich EJ, Schraner C, Boesch C, Hodler J, Busato A, Anderson SE. Normative MR cervical spinal canal dimensions. Radiology 2014;271(1):172-82.

10. Hashimoto I, Tak Y-K. The true sagittal diameter of the cervical spinal canal and its diagnostic significance in cervical myelopathy. J Neurosurg 1977;47(6):912-6.

11. Goto S-I, Umehara J, Aizawa T, Kokubun S. Comparison of cervical spinal canal diameter between younger and elder generations of Japanese. J Orthop Sci 2010;15(1):97-103.

12. Morishita Y, Naito M, Wang JC. Cervical spinal canal stenosis: the differences between stenosis at the lower cervical and multiple segment levels. Int Orthop 2011;35(10):1517-22.

13. Prasad SS, O'Malley M, Caplan M, Shackleford IM, Pydisetty RK. MRI measurements of the cervical spine and their correlation to Pavlov's ratio. Spine 2003;28(12):1263-8.

14. Okada Y, Ikata T, Katoh S, Yamada H. Morphologic analysis of the cervical spinal cord, dural tube, and spinal canal by magnetic resonance imaging in normal adults and patients with cervical spondylotic myelopathy. Spine 1994;19(20):2331-5.

15. Sherman JL, Nassaux PY, Citrin CM. Measurements of the normal cervical spinal cord on MR imaging. AJNR Am J Neuroradiol 1990;11(2):369-72.

16. Yanase $M$, Matsuyama $Y$, Hirose $K$, Takagi $H$, Yamada $M$, Iwata $H$. Measurement of the cervical spinal cord volume on MRI. Clin Spine Surg 2006;19(2):125-9.

17. Torg JS, Naranja Jr RJ, Pavlov H, Galinat BJ, Warren R, Stine RA. The relationship of developmental narrowing of the cervical spinal canal to reversible and irreversible injury of the cervical spinal cord in football players. An epidemiological study. JBJS 1996;78(9):1308-14.

18. Nell C, Bülow R, Hosten N, Schmidt CO, Hegenscheid K. Reference values for the cervical spinal canal and the vertebral bodies by MRI in a general population. PloS one 2019;14(9):e0222682. 